\title{
Energy efficiency determinants: An empirical analysis of Spanish innovative firms
}

\author{
María Teresa Costa-Campi, Department of Public Economics, Chair of Energy Sustainability \\ and Barcelona Institute of Economics (IEB), University of Barcelona \\ Av/Diagonal 690. 08034 Barcelona, Spain \\ Tel.: +34 9340218 12. Fax: +34934021813 \\ E-mail:mtcosta@ub.edu
}

José García-Quevedo, Department of Public Economics, Chair of Energy Sustainability and Barcelona Institute of Economics (IEB) University of Barcelona

E-mail: jgarciaq@ub.edu

\author{
Agustí Segarra, GRIT, CREIP, Rovira i Virgili University \\ E-mail: agusti.segarra@urv.cat
}

\begin{abstract}
This paper examines the extent to which innovative Spanish firms pursue improvements in energy efficiency (EE) as an objective of innovation. The increase in energy consumption and its impact on greenhouse gas emissions justifies the greater attention being paid to energy efficiency and especially to industrial EE. The ability of manufacturing companies to innovate and improve their EE has a substantial influence on attaining objectives regarding climate change mitigation. Despite the effort to design more efficient energy policies, the EE determinants in manufacturing firms have been little studied in the empirical literature. From an exhaustive sample of Spanish manufacturing firms and using a logit model, we examine the energy efficiency determinants for those firms that have innovated. To carry out the econometric analysis, we use panel data from the Community Innovation Survey for the period 2008-2011. Our empirical results underline the role of size among the characteristics of firms that facilitate energy efficiency innovation. Regarding company behaviour, firms that consider the reduction of environmental impacts to be an important objective of innovation and that have introduced organisational innovations are more likely to innovate with the objective of increasing energy efficiency.
\end{abstract}

Keywords: energy efficiency, corporate targets, innovation, Community Innovation Survey

JEL Classification: Q40, Q55, O31 


\section{Introduction}

The increase in energy consumption and its influence on greenhouse gas emissions justifies the greater attention being paid to energy efficiency (EE) and especially to industrial EE. There is a global consensus on the correlation between energy consumption increases and rising greenhouse gas emissions. EE is the most advantageous way to enhance both the security of the energy supply and of decreasing greenhouse gas emissions and other pollution (EC, 2011). It is estimated that around $60 \%$ of the reduction of greenhouse gas emissions necessary to achieve the 2020 targets defined by the International Energy Agency (IEA) can be obtained through EE improvements (IEA, 2009). The economic literature has also contributed to underlining the role that technological improvements can play in reducing carbon emissions and lowering the cost of this reduction (Jaffe et al., 2004; Popp et al., 2009).

EE improvements at the current level are not enough to ameliorate the effects of increasing worldwide energy demand. However industrial sector reports show that the implementation of existing technology and best practices on a global scale could lead to savings of between $18 \%$ and $26 \%$ of current industrial primary energy consumption (IEA, 2008). At the same time, a large number of studies of EE potential indicate that EE cost-effective measures are often not carried out in the industrial sector because of market failures and market barriers, bounded rationality and organizational problems, among other things (Backlund et al., 2012; Brown, 2001; Hirst and Brown, 1990; Jaffe et al., 2004; Linares and Labandeira, 2010; Palm and Thollander, 2010; Trianni and Cagno, 2012).

Energy efficiency in general, and particularly in the industrial sector, is an important way to reduce the threat of global warming, bearing in mind that industry is one of the main energy consumers (IEA, 2013). The European Commission (EC) promotes industrial EE through new energy requirements for industrial capital goods, improvements in the provision of information to SMEs, and measures encouraging the introduction of energy audits and energy management systems (EMS). The EC is also considering efficiency improvements in power and 
heat generation, ensuring that plans include EE measures throughout all the supply chain (EC, 2011).

The literature is not conclusive with regard to the influence EE has in terms of business performance. Neither does any unique criterion exist on the optimal level of EE (Jaffe and Stavins, 1994). Besides their impact on greenhouse gas emission mitigation, it seems that $\mathrm{EE}$ investments are associated with improvements in technological development and innovation in firms. The debate centred exclusively on cost savings derived from EE improvements now turns out to be a very limited approach. For the reasons given above, EE is part of the environmental agenda (Worrell et al., 2009). The contributions from the literature on the impact of eco-innovation and environmental policy on company innovation decisions widen the scope of analytical procedure to more than that exclusively focused on cost savings. Porter and Van der Linde's (1995) article, which introduced a new approach based on the existence of a positive relationship between environmental policies and innovations that enhance product quality, cost savings, and finally company competitiveness, facilitates the study of EE from a new perspective

One of the challenges facing the study of EE is to identify the characteristics of firms that drive the adoption of EE improvements in order that policy can be correctly designed. This should become an important objective for the Spanish economy, where energy intensity rose $10 \%$ between 1990 and 2006 while in the EU15 it fell in the same period (Mendiluce et al., 2010). Although in recent years this trend has apparently improved, basically because of the economic crisis, Spain still leads EU countries in energy intensity (IDAE, 2013). Existing studies corroborate the possibility that the reduction of inequalities in energy intensity between countries could be attributed to the adoption of EE improvements (Greening et al., 1997; Duro et al., 2010). Despite the importance of EE in reaching the economic and environmental sustainability objectives of the Climate Energy Package, the results obtained to date are not very encouraging. The large share of final energy consumption taken up by Spanish industry 
together with the limited incentives provided for companies to adopt process innovations intended to improve EE explain the poor progress registered at macroeconomic level.

This paper examines the characteristics of manufacturing firms associated with energy efficiency innovations in a novel way. Many studies have analysed the role of barriers to the adoption of energy efficiency measures by firms while others have focused on the adoption rate of the energy efficiency measures recommended by energy audits (Fleiter et al., 2012; Sorrell et al., 2011; Trianni and Cagno, 2012). In this paper we analyse energy efficiency from the perspective of innovation objectives. In general, empirical research on innovation at the firm level has yet to incorporate the role of objectives (Leiponen and Helfat, 2010). In our analysis, we specifically examine energy efficiency technological innovation departing from information about the motives and objectives that firms have for innovating. While many papers have analysed eco-innovations in general, we focus on energy efficiency innovation where both competitive and environmental objectives play a significant role, which deserves specific attention.

In order to carry out this analysis, we use an exhaustive sample of innovative firms from the Innovation Technology Panel (PITEC), which offers access to a broad sample of Spanish innovative companies. The paper has two main objectives. First, it goes in depth into the profile of firms that pursue improvements in EE levels among their innovation objectives. Second, the paper analyses whether the behaviour of firms around organizational innovations and the reduction of environmental impact is related to the EE objectives that Spanish manufacturing firms are pursuing. By EE we understand action taken by firms that has the objective of reducing the amount of energy per unit output.

The rest of the paper is organized as follows. The following section briefly reviews the literature and empirical studies. Section 3 describes the data employed in the empirical analysis and the variables used for the estimations. Section 4 illustrates the econometric strategy and presents the results. Section 5 concludes and discusses policy implications. 


\section{Literature review and empirical studies}

There is a broad debate in the economic literature about the benefits of EE. Several contributions state that a large proportion of the industrial sector has not implemented EE improvements despite the fact that they are associated with greater profits rather than costs (Backlund et al., 2012; Brown, 2001; Hirst and Brown, 1990; Palm and Thollander, 2010; Trianni and Cagno, 2012). On the other hand there is a current of thought that argues that EE improvements, far from reducing energy consumption, increase it - 'Jevons' Paradox' -, the so called 'Rebound Effect', that leads to a lowering of prices, at first, and then a subsequent increase that removes the cost savings (Greening et al., 2000; Khazzom, 1980; Sorrell, 2009).

The differences between the EE improvements actually achieved and those considered to be socially optimal have been defined by the literature, from different points of view, as the 'Energy Efficiency Gap' (Jaffe and Stavins, 1994). The most widespread formulation maintains that the 'gap' appears when EE investment is below the socially optimal, in economic and environmental terms (Gillingham et al., 2009). Another reformulation of the same idea considers the 'gap' can be explained as the use of high 'implicit' ${ }^{1}$ discount rates to evaluate EE investment decisions, greater than those that are accepted as optimal by the market for other investments with the same risk (Jaffe and Stavins, 1994).

The 'Energy Efficiency Gap' is considered to be the consequence of the existence of numerous market failures, which are understood as deviations from the assumptions of perfect competition, such as barriers associated with economic, organizational and behavioural obstacles and the lack of adoption of organizational innovations in EE management (Backlund et al., 2012).

The debate focuses on the distinction between market failures and market 'barriers'. The economic approach, which is lead by Sutherland (1991) and Jaffe and Stavins (1994), argues

\footnotetext{
${ }^{1}$ The 'implicit' discount rate refers to the expected rate of return required for an investment to be considered cost-effective.
} 
that public policy can only try to address market failures like imperfect information, R\&D spillovers or principal-agent problems, among other things. On the other hand the technological approach maintains that public policy should attempt to remove all the barriers, whether they are market failures or not ${ }^{2}$ (Brown 2001; Hirst and Brown, 1990). Those favouring the economic approach are against using public policy to overcome these barriers, because the cost of implementation exceeds the possible gains in EE. From more extreme positions it is argued that if it is accepted that private agents take their own investment decisions seeking their own interest (complete rationality), it would be understandable that when they observe the existence of market failures and market barriers they use higher discount rates to evaluate investment decisions as they are faced with greater risk or uncertainty, and this would lead us to the conclusion that no paradox exists in the 'Energy Efficiency Gap' (Sutherland, 1996).

The most recent literature highlights the importance of the technological-organizational approach in the design of policies for dealing with barriers (Backlund et al., 2012). Increasing concern about the environmental agenda has converted EE and reducing the 'Gap' into fundamental targets, not only in economic terms (cost savings), but also in the fight against climate change (Worrell et al., 2009; Worell, 2011). In this context the EU agrees with the technological approach in the debate about the 'Gap'. The definition of the Energy Services Directive (ESD) is an example, which defends the idea that it is only possible to reach the social optimum of EE by applying strict policies to ameliorate market failures as well as market 'barriers' (Backlund et al., 2012).

In empirical analysis the literature has attempted to identify barriers that hinder the adoption of EE investments (Anderson and Newell, 2004; de Groot et al., 2001; Fleiter et al., 2012; Rohdin and Thollander, 2006; Trianni and Cagno, 2012). However, the number of contributions

\footnotetext{
${ }^{2}$ Considered to be non-market failures are uncertainty about future energy prices, uncertainty about expected savings from the adoption of new technology, the qualitative characteristics of new technologies that make it less desirable, adoption costs not included in investment cost-effectiveness calculation or the heterogeneity of the consumers, and inertia, among others.
} 
that study the link between EE and innovation is still small, and even more so with regard to the factors that influence the EE improvements by innovative firms (De Marchi, 2012; Horbach et al., 2012; Rennings and Rammer, 2009; Trianni et al., 2013). Some of these studies use data from the CIS (Community Innovation Survey) and tend to search for explanations for the decisions of innovative companies about investing in eco-innovation and/or $\mathrm{EE}$, in some cases using logit and probit models or matching approach techniques.

The estimations carried out tend to identify a group of variables that influence EE improvement. Size is a significant variable in almost all the studies; institutional support for R\&D in the form of subsidies and fiscal credits (Luiten et al., 2006; Luiten and Block, 2003), the ability to export and the export orientation of the country in which the firm is located (Urpelainen, 2011), and the sectoral characteristics associated with the energy intensity of the productive process (De Groot, 2001; De Marchi, 2012) explain EE investment decisions. It has also been found that regulation and cost savings (Horbach et al., 2012), and the introduction of environmental management systems and organizational changes favour innovation in environmental improvement (Khanna et al., 2009).

The literature shows that certain characteristics of firms influence the adoption of innovative environmental technologies (Uhlaner et al., 2011). For example, to mitigate the problem of barriers it is crucial to determine the characteristics that differentiate eco-innovative companies. To have this information available could facilitate the discovery of the origin of the barriers and could be considerably useful to the companies themselves and to policy-makers when attempting to overcome existing limitations to the introduction of EE improvements. However more effort in this direction is required by researchers to identify these characteristics when the adoption of technology for EE improvements is being considered (Trianni et al., 2013).

Some empirical studies analyse the specific characteristics of eco-innovative firms in the field of EE. In an early approach, DeCanio and Watkins (1998) argued that the characteristics of 
each firm itself (such as the size, capital cost, expected future incomes and sector) influence decisions to invest in EE improvements. Rennings and Rammer (2009) attempt to explain the differences between innovative firms that introduce EE improvements and other innovative firms. To do so they use data from the German CIS, and the results they obtain are that firms that introduce innovations in EE: i) are more productive, ii) assign a larger share of sales to $R \& D$, iii) obtain greater cost savings from the innovation process, iv) use more sources of information, v) cooperate more with the firms in their group, and vi) perceive innovation barriers more intensely.

Finally, Horbach et al. (2012), despite studying the determinants of eco-innovation in general, establish a distinction according to the areas of impact of the innovation, which allows the identification of the determinants of EE innovations. The results show that the reasons that lead companies to adopt EE innovations are mainly focused on cost savings; but there is still an important component of environmental impact reduction. Other characteristics of ecoefficient innovative firms that emerge from the same paper are changes in the organization of work to improve EE and cooperation with universities in the innovative process. At the same time future regulation and market demand are notably key factors in introducing more EE in the final product. The study by De Marchi (2012), which attempts to explain the link between cooperation and eco-innovation, also includes eco-efficiency in a part of the model. The results obtained show that cooperation, continuity in carrying out R\&D, firm size and investment in capital goods also benefit EE innovation.

\section{Data sources and variables}

The data source used is the Technological Innovation Panel (PITEC). This data panel was the outcome of a cooperative project undertaken by the National Institute of Statistics (INE), the Spanish Foundation for Science and Technology (FECYT) and the COTEC Foundation. The INE has been carrying out a Community Innovation Survey (CIS) since 1994. The Spanish version of 
the survey includes sections on the introduction of innovations, expenditure on innovation, barriers to innovation and the results that firms obtain when they innovate, amongst other topics.

The main objective of the PITEC Project is to provide researchers with direct access to anonymized data. At the moment, PITEC supplies information that covers the period 20032011. The CIS for Spain has over time included new questions that were not formulated in the first editions in order to address new lines of work and analysis. In particular, in 2008, firms were asked for the first time what goals they were pursuing when they introduced innovation into products or processes, offering the chance to make an independent analysis of energy efficiency-related objectives ${ }^{3}$; in 2009 , the twelve objectives added the previous year were expanded with three new objectives related to employment.

One of the main advantages of the PITEC database compared with sources containing crosssectional data is its time dimension. This characteristic allows researchers to address the behaviour of the company and the level of heterogeneity between firms with more precision. One of the limitations of the CIS survey is the subjective nature of many of the questions addressed to the firm's management or those responsible for R\&D departments. Nevertheless, the comparisons made by Mairesse and Mohnen (2005) suggest that subjective assessments concerning business innovation tend to be consistent with more objective evaluations.

Our definitive database is the result of a prior filtering process. The most important filtering criteria were as follows: a) the survey data cover the period 2008-2011 as the INE's CIS survey only included the objectives pursued by innovative firms in 2008; b) the sample covers those Spanish manufacturing firms that innovated in processes or products, given that the question 'How important were each of the following objectives for your activities to develop product or

\footnotetext{
${ }^{3}$ The 2008 questionnaire introduces the question "How important were each of the following objectives for your activities to develop product or process innovations during the three last years?" In addition, the survey asked firms to grade the importance of each objective identified (High, Medium, Low or Not relevant), and distinguishes between reducing material per unit output and reducing energy per unit output.
} 
process innovations during the three last years?' was aimed at those firms ${ }^{4}$. Of the 5,721 companies identified as Spanish manufacturing firms, after applying the relevant filters, the final sample comprised 4,458 firms that innovate in processes, products, or both.

Table 1

As shown in Table 1, 66.2\% of Spanish manufacturing firms made some kind of process innovation, while $77.9 \%$ of firms made innovations in products and/or processes. These data demonstrate that innovations in products and processes have high levels of complementarity, and the benefits of undertaking them both together are greater than those achieved by pursuing product or process innovations separately (Tirole, 1988, De Marchi, 2012). This evidence highlights the presence of indivisibility in the tangible and intangible assets associated with innovation processes and the prominence of economies of scope and scale.

Table 2 presents the variables used in the empirical analysis. The dependent variable is dichotomous and takes the value of 1 when the firm seeks energy efficiency as an objective of innovation (with a medium or high level of importance) and zero when this objective has a low or insignificant level of importance. The percentage of firms that state that energy efficiency is an innovation objective of medium or high importance is $43.6 \%$. This percentage is lower than other objectives for process innovations such as reducing labour cost per unit output (53.7\%) or increasing capacity for producing goods (61\%). The energy efficiency objective also shows a lower degree of persistence than process innovation in general. While $51.2 \%$ of the firms that state that this objective was important in the 2006-2008 period also consider it important in 2009-2011, this percentage rises to $80.1 \%$ for process innovation in general. This difference may be related to the fact that innovation in energy efficiency is closely related to investment

\footnotetext{
${ }^{4}$ This question is also asked to firms that have ongoing or abandoned innovation activities. Nevertheless, as is explained in the next section, we focus our analysis on firms that have introduced product or process innovations.
} 
in tangible assets. Therefore, once the investment in reducing energy per unit output has been made, it is for some years less probable that it will be necessary to invest in the same objective.

The determining factors of energy efficiency in manufacturing firms can be broken down into two groups. Firstly, there is a set of variables related to the individual characteristics of firms such as size, age, productivity, exports, whether or not they belong to a group of companies and nationality. Secondly, there is another set of variables associated with the behaviour of firms that the literature frequently considers to be facilitators of the adoption of strategies related to energy efficiency - investment in R\&D, investment in tangible assets, organizational innovations and access to public subsidies.

Table 2

The profile of firms giving a high level of importance to energy efficiency-related innovations differs significantly from those that do not. The first group present greater sensitivity to environmental improvements and compliance with current legislation, they have a higher number of employees, are more productive, invest more intensively in tangible assets, are more likely to belong to Spanish or foreign business groups and, finally, along with their technological innovations, also practiced organizational innovations in terms of their working methods, internal logistics, incentives and quality systems, amongst other factors.

The values reflected in the different approaches of the two subgroups (firms that demonstrate little interest in pursuing energy efficiency compared to those that place energy efficiency among their main objectives), together with the substantial significance of the test, suggest the presence of structural differences. Indeed, the differences in profiles between the two subgroups greatly conditions the behaviour that determines the probability of each firm adopting the reduction of energy per unit of product as a strategic objective of innovation. 
Table 3

Firm propensity to innovate in energy efficiency may be affected by sectoral specificities. Sectors present a high degree of heterogeneity in some factors that drive their innovative behaviour. In particular, in energy efficiency innovation, there is a strong correlation between competitiveness objectives and environmental ones and there are substantial industry differences regarding energy intensity and environmental regulation. The data for energy intensity show that four sectors are very energy intensive, with percentages higher than $5 \%$ (Table 4). These four sectors (paper, chemicals, non-metallic minerals and metals and metal products) are also affected by the 2005 emissions reduction and trading directive (European Union ETS). Therefore, the estimations have also been carried out for each of these four sectors that present specific characteristics that justify an individual approach.

Table 4

\section{Econometric analysis, results and discussion}

Because the dependent variable is binary, a logit model is used. Specifically, the next equation is estimated:

$$
\operatorname{Prob}(E E)_{i t}=\beta_{0}+\beta_{1} X_{i t}+\beta_{2} I N N_{i t}+\alpha_{t}+\varepsilon_{i t}
$$

where $\mathrm{EE}_{\mathrm{it}}$ is the importance given to energy efficiency innovation. The explanatory variables, as we have mentioned above, include a set of firm characteristics $(X)$ and another set of variables associated with the innovation strategies and behaviour (INN) of the firm (see Table 5 for the correlation matrix). The estimations have been carried out for the manufacturing industry, for the four sectors mentioned in the previous section (paper, chemicals, non- 
metallic minerals and metals and metal products) and, as a robustness check, for all the other sectors except for these four.

Table 5

In the estimations for the whole sample, industry fixed effects have been included with the maximum level of disaggregation that the database allows (20 industry dummies). With the inclusion of these fixed effects any specific industry characteristic that can affect the firm's likelihood of considering energy efficiency innovation to be of high or medium importance is controlled for. In all the estimations time dummies are also included to control for cyclical effects.

Even though panel data is available, a pooled logit estimation has been carried out for the whole period. The period for which the dependent variable data is available is very short (four years) and the main variation in the data is cross-sectional, whereas there is little variation over time, particularly as the time span of the analysis is short. Most of the independent variables like R\&D activities and exports are highly persistent and particularly for the dummy variables regarding belonging to a group, the presence of foreign capital, public funding, ecoinnovation, meeting regulatory requirements and organizational innovation there is very little variation over time. The information from the survey for the last three of these variables also has a high degree of overlap because the Community Innovation Survey poses these questions for time spans of three years and not for the current year. The calculus of the transition probabilities matrix shows that the probability of remaining in the same status are greater than 0.8 for these three variables. In the estimations, robust standard errors clustered at firm level have been used to control for intra-firm serial correlation. The sample used in the estimations corresponds to the firms that have introduced product or process innovations. An alternative sample would be one also including the firms that have ongoing or abandoned 
innovation activities. Because our main objective is to examine the characteristics of the firms that have introduced energy efficiency innovations, we consider it preferable to focus only on innovative firms. Nevertheless, we have also carried the estimations out for the sample that includes the firms that have ongoing or abandoned innovation activities and the results regarding the sign and the significance of the parameters are identical.

Our empirical procedure could suffer from sample selection because the importance given to energy efficiency innovation is only observed for firms that have introduced product or process innovations or have ongoing or abandoned innovation activities. As pointed out above our interest lies in behaviour in innovation in energy efficiency and therefore we focus our analysis on a sample of innovative firms that also allows sample selection problems to be avoided. Finally, we have also carried out a probit estimation that yields similar results with the same variables being significant. Together with the estimation results, we also report the marginal effects that show how marginal changes in the independent variables would affect the predicted probabilities of innovating in energy efficiency (Tables 6 and 7).

These results show that some characteristics of firms influence energy efficiency innovations. First, size and export propensity have positive and significant parameters, a result that coincides, in the case of size, with the results obtained in other studies (DeCanio and Watkins, 1998; De Marchi, 2012; Veugelers, 2012), but not in the case of export propensity, which has been little studied and has not been found to be significant (De Marchi, 2012). In spite of that, both are considered to be structural variables in eco-innovation processes (Segarra-Oña et al., 2011; De Marchi, 2012). The results obtained in this estimation for exporting, unlike those of De Marchi (2012), suggest that those firms that are more competitive and have a greater international market presence have a higher propensity to introduce energy efficiency related innovations. The results also show that better performing firms, measured by productivity levels, are more likely to consider the objective of energy efficiency innovation important, as also pointed out for Germany by Rennings and Rammer (2009). Other empirical analyses that 
examine the features of environmental innovators also introduce sales per employee into the estimation as an explanatory variable, obtaining a positive and significant parameter (Del Rio et al., 2013, Demirel and Kesidou, 2011). In contrast to the results for the whole industry, in the individual estimations for more energy intensive sectors, neither of the variables, size or export, are significant, which suggests that all types of firms in these sectors consider energy reduction per output unit to be very important. Similarly, productivity is not significant except in the case of metallurgy industry and manufacture of fabricated metal products.

To analyse the extent to which size may be a barrier to innovation in energy efficiency in more detail we have also carried out the estimations substituting the continuous variable of size with two dummies corresponding to small firms (from 1 to 49 employees) and medium firms (50-249). The results reinforce our conclusions and show, for the general estimation, that size is an important variable in explaining energy efficiency innovations. The parameters for the two dummies are negative and significant. For the more energy intensive industries, the results are similar to those obtained with the number of employees (in logs). The parameters for the dummies are not significant except for medium-size firms in the paper industry where the parameter is positive and significant.

Other characteristics of firms such as age are not significant in explaining the introduction of energy efficiency innovation. These results coincide with those of other studies (Horbach et al., 2012; Veugelers, 2012). However, being part of a group of companies is significant and favours innovation with an energy efficiency objective. The exploitation of synergies between companies in the group is useful in overcoming existing barriers to eco-efficiency innovation. Second, for innovation in the field of energy efficiency, capital goods investment is important, a result that coincides with that obtained by De Marchi (2012), while neither internal R\&D nor external R\&D are significant in our estimations. Consequently the type of process innovation that is carried out does not seem to need a great R\&D effort while the introduction of tangible assets that permit process innovation resulting in reduction of energy per unit output is 
required. By sectors, investment has a positive parameter for the paper, metal and metal products industries while in none of the four sectors is there a positive relationship between internal or external R\&D and energy efficiency innovation. These results obtained for the most intensive energy sectors reinforce the conclusion that innovation in energy efficiency is more related with technology improvements embodied in capital goods than with new knowledge generated through an effort in internal or external R\&D. In other applied studies on energy efficiency the results are similar to those of Horbach et al. (2012) and De Marchi (2012) in which neither internal nor external R\&D are significant in the introduction of greater ecoefficiency.

Tables 6 and 7

Third, there is no relation between public R\&D subsidies and energy efficiency innovation. The estimations by sectors show the robustness of this result and in none of the four cases is a significant parameter obtained. The existing literature also confirms this result, and in the studies of both eco-innovation and eco-efficiency models the public funds variable is only significant in the first whereas if the analysis is limited to energy efficiency innovation no positive effect is found (Horbach et al., 2012; De Marchi, 2012).

Finally, energy efficiency innovation is closely related to other innovation objectives. The parameters for the innovation objectives "reduce environmental impact" and "to meet legal requirements" are positive and highly significant. In particular, the marginal effects of the variable environmental impact innovation objective are particularly large. The predicted probability of observing energy efficiency in the estimation for all firms is 0.365 greater for the firms that report that environmental impact is of medium or high importance than for those stating that it has low or no importance. Other empirical studies also show evidence of this close link with environmental objectives (Horbach et al., 2012; 2013, Del Río et al., 2013). The 
results of the estimations together with the correlation matrix (see Table 5) show the existence of strong relationships between energy efficiency objectives, environmental objectives and innovation to meet regulatory requirements. Regulations focused on energy efficiency make firms into eco-innovators (Demirel and Kesidou, 2011). Meeting the regulatory challenge to improve energy efficiency stimulates business investment in new technologies. This innovation objective brings with it the introduction of innovation in machinery and equipment, in the organisation of the enterprise and in its relationship with its context. The results suggest that innovative firms that pursue energy efficiency objectives are environmentally friendly. The adoption of self-regulatory measures on environmental issues could be seen as a new strategy choice in accordance with criteria defended by smart investors and stakeholders.

Nevertheless, some analyses (Horbach et al., 2012) claim that regulation seems to be important for many environmental innovations but not specifically for the use of energy, while others (Veugelers, 2102) show that current and future regulations affect innovation behaviour that has the objective of reducing energy consumption. To disentangle the relationships between these three objectives of innovation, increasing energy efficiency, reducing environmental impact and meeting regulations, and to determine causal linkages would require having panel data with a sufficiently long time dimension, something that is not currently available.

Additionally, there is also a positive relation between organizational innovation and energy efficiency innovations, suggesting that this type of innovation goes together with changes in firm practice and procedures in the production area. The introduction of energy management systems inside companies offers new potential for energy efficiency improvements (Backlund et al., 2012). Energy efficiency improves through the investment in and the adoption of new technologies but, at the same time, these investments require changes and innovations in the organisation of the firm in order to be adequately implemented. 
The results regarding the positive effects of eco-innovation, meeting regulatory requirements, organisational innovation and energy efficiency innovation are also obtained for the individual estimations by sectors, with some exceptions in the paper industry. These results highlight the great importance of these factors in explaining innovation that seeks to improve energy efficiency at a firm level. In particular, the marginal effects show the strong relation between environmental and energy efficiency objectives in the four sectors and also in industry as a whole. In the case of the paper industry, the meeting regulations innovation objective and organisational innovation are not significant. The pulp and paper industry has merited special attention in the literature on energy efficiency and eco-innovation (see, among others, Del Río, 2005). In our sample, this industry has the highest percentage of firms that consider energy efficiency to be an important motive for innovation (58.1\%) and the degrees of correlation of this objective with the environmental one and with meeting regulatory requirements are also very high and above the average. In addition, the pressure of regulation has been a very important driver of the implementation of clean technologies in this industry, (Del Río, 2005) which has led to a strong correlation between environmental innovation objectives and innovations with the objective of meeting regulatory requirements ${ }^{5}$.

\section{Conclusions and policy implications}

From the climate change mitigation perspective, improving energy efficiency in the manufacturing sector is an important way of reducing the threat that global warming represents. Despite its importance, the determinants of energy efficiency innovation at firm level have scarcely been addressed.

\footnotetext{
${ }^{5}$ In our sample the correlation between these two objectives of innovation is very high (0.752). This may affect the estimation results and explain the non-significant parameters obtained for the variable regulation. In additional estimations carried out without introducing the eco-innovation variable the parameters for regulation and organisational innovation in this industry are positive and significant.
} 
The empirical evidence in this paper shows that a firm's profile is clearly a key factor when it comes to introducing innovations aimed at improving energy efficiency levels. For the manufacturing sector, the empirical results show that the size of the firm and focusing on foreign markets are important variables.

Variables relating to the firm's behaviour also produce revealing results. Investment in tangible assets has a direct relationship with a commitment to energy efficiency, while investments in R\&D per employee do not directly affect the firm's capacity to improve its energy efficiency. Improvements in energy efficiency are associated with the introduction of more efficient machinery, the introduction of the use of sustainable materials and the development of processes that are less reliant on the intensive use of technology, all of which are associated with investment in tangible assets and have little to do with R\&D activity per se.

Additionally, the econometric estimations show that environmental and energy efficiency objectives complement each other and that it is often the case that the innovative firm addresses them together, either as a result of the firm's own sensibilities or through the retroactive effects generated by the firm pursuing both objectives. Together with this result, it is worth highlighting the importance of organizational innovations as a key factor related to energy efficiency improvements. In synthesis, the results obtained show that the profile of manufacturing firms, along with their adoption of specific strategies - especially investment in tangible assets, organizational innovations and measures relating to the environment increase the probability that an innovative company will place energy efficiency among its objectives.

These results highlight the need to design cross-cutting policies that generate incentives for innovative firms in the Spanish manufacturing sector to jointly tackle the challenges associated with energy efficiency and environmental sustainability without compromising the firm's competitiveness. Given that there is a gap between optimum levels of energy efficiency and those that are actually achieved, a wide-ranging series of public measures should be called for 
to encourage the adoption of technology and working patterns that not only improve firms' energy efficiency but also increase the productivity and competitiveness of manufacturing firms.

Therefore, improving energy efficiency should be placed within the framework of environmental sustainability and innovation policies. The results obtained show, on the one hand, that regulation and self-regulation act with the same objective in the context of innovation and, on the other, that the objective of energy efficiency innovation is achieved in firms with economies of scale, in competitive environments and that are integrated into holding companies. From this can be inferred the need to coordinate environmental and innovation policies. The success of regulation and instruments to foster innovation to improve energy efficiency rests upon their ability to create an environmentally friendly market dynamic.

According to that statement it corresponds to regulation policy to set objectives for energy efficiency improvement for manufacturing firms. Energy efficiency is an intermediate objective associated with an environmental sustainability policy that demands the implementation of binding commitments that stimulate the incorporation of technological changes and the adoption of innovations. That means good regulation should lead firms towards ecoinnovation. The regulation of labels and the certification of innovations that improve energy efficiency and compulsory energy audits are suitable instruments for facilitating meeting the binding objectives of energy efficiency. These measures can be reinforced with the obligation to buy, in the event, emission allowances in accordance with the rules of the EU Emissions Trading System (EC $(2014, a, b)$. These measures would make it necessary to incorporate new technologies and to adopt innovations in processes and in organisation forwarding the objective of energy efficiency innovation and environmentally oriented self-regulation. Selfregulation can be supported by smart regulation measures. The defence of best business practice in energy efficiency innovation and environmental matters, information about 
improving the energy efficiency of the firm, the creation of rankings and recognition through awards would create spillover effects and help to identify the behaviour of every company. This is valued by smart investors, as is shown by the indicators Sustainability Yearbook, CDP Global 500 Climate Change Report, Global 100 and Newsweek Green Rank.

Another area for action is in addressing market failures that prevent companies from implementing innovations and obtaining improvements in energy efficiency. To do so it is necessary to deploy instruments that foster innovation, directly or indirectly connected to energy efficiency innovation. In this case support should be provided for the incorporation of the technological assets necessary to reduce energy intensity and access to the appropriate skills for their use should be facilitated. The design of suitable financial facilities for the renovation of assets, the promotion of innovative energy efficiency technologies, and support for the training and organizational changes required by these technologies would permit greater innovations to be implemented and involve new companies in attaining the objective of energy efficiency. The lowering of barriers to information, particularly the asymmetric ones, is also an important area in which policy can act.

To implement these policies and to advance in our understanding of the factors that explain the gap between the optimal and the current level of energy efficiency requires a more detailed analysis of the resources allocated to innovating in energy efficiency and of the barriers that firms face in reducing their energy costs. Our analysis has focused on the decision to innovate to improve energy efficiency but not on the intensity or on the amount of resources allocated to this objective of innovation because of information constraints. To have information on the number of innovations and on the intensity and resources allocated to this objective by firms would allow our knowledge to be improved about the drivers of innovation in energy efficiency and about the effects of some explanatory variables. For example, it would make it possible to examine in more depth non-linear relationships between size and energy efficiency or the impact of eco-innovation and organisational innovation on the innovative 
effort of firms to improve energy efficiency. Further research would also complement the analysis of the characteristics of the firms carried out in this paper with analyses regarding the obstacles that may hamper the introduction of innovations that have the objective of increasing energy efficiency. While the literature has described the different barriers related to energy efficiency and proposed some taxonomies, the empirical analyses carried out to date do not allow definite conclusions to be drawn. 
Acknowledgements: We are very grateful for the suggestions and comments of two anonymous referees that were very useful in improving the paper. We are grateful to Verònica Gombau and Xavier Massa for their excellent research assistance. The authors would also like to thank J. Batalla and E. Trujillo for valuable comments. Previous versions of this paper were presented at the Workshop on Economics of Energy Efficiency (Reus, Spain, December, 2013), at the ESRC Seminar Series "Technological innovations for transitioning to a low-carbon economy" (Warwick, United Kingdom, January, 2014), at the International Academic Symposium "R\&D on Energy" (FUNSEAM, IEB-UB, Barcelona, Spain, January, 2014), at the IX Conference of the Spanish Association for Energy Economics (Madrid, Spain, February 2014), and at the $37^{\text {th }}$ IAEE International Conference (New York, United States, June, 2014). We would like to thank the participants at these meetings for their helpful comments. We acknowledge financial support from the Chair on Energy and Environmental Sustainability (University of Barcelona and FUNSEAM). We would also like to thank the Xarxa de Referència en Economia Aplicada (XREAP) for their support. 


\section{References}

Anderson, S. T., Newell, R. G., 2004. Information programs for technology adoption: the case of energy-efficiency audits. Resource and Energy Economics, 26, 27-50.

Backlund, S., Thollander, P., Palm, J., Ottosson, M., 2012. Extending the energy efficiency gap. Energy Policy, 51, 392-396.

Brown, M. A., 2001. Market failures and barriers as a basis for clean energy policies. Energy Policy, 29, 1197-1207.

DeCanio, S. J., Watkins, W. E., 1998. Investment in energy efficiency: do the characteristics of firms matter?. Review of Economics and Statistics, 80, 95-107.

De Groot, H. L., Verhoef, E. T., Nijkamp, P., 2001. Energy saving by firms: decision-making, barriers and policies. Energy Economics, 23, 717-740.

De Marchi, V., 2012. Environmental innovation and R\&D cooperation: Empirical evidence from Spanish manufacturing firms. Research Policy, 41, 614-623.

Del Río, P., 2005. Analysing the factors influencing clean technology adoption: A study of the Spanish pulp and paper industry. Business Strategy and the Environment 14, 20-37.

Del Río, P., Peñasco, C., Romero-Jordán, D., 2013. Distinctive features of environmental innovators: An econometric analysis. Business Strategy and the Environment, published online. DOI: $10.1002 /$ bse.1822.

Demirel, P., Kesidou, E., 2011. Stimulating different types of eco-innovation in the UK: Government policies and firm motivations. Ecological Economics, 70, 1546-1557.

Duro, J. A., Alcántara, V., Padilla, E., 2010. International inequality in energy intensity levels and the role of production composition and energy efficiency: An analysis of OECD countries. Ecological Economics, 69, 2468-2474.

EC, 2011. Communication from the Commission to the European Parliament, the Council, the European Economic and Social Committee and the Committee of the Regions. Energy Efficiency Plan 2011. COM(2011) 109 final. European Commission, Brussels. 
EC, 2014a. Communication from the Commission to the European Parliament, the Council, the European Economic and Social Committee and the Committee of the Regions. A policy framework for climate and energy in the period from 2020 to 2030. SWD(2014) 15 final, SWD(2014) 16 final. European Commission, Brussels.

EC, 2014b. Communication from the Commission to the European Parliament and the Council. Energy Efficiency and its contribution to energy security and the 2030 Framework for climate and energy policy. SWD(2014) 255 final, SWD(2014) 256 final. European Commission, Brussels. Fleiter, T., Schleich, J., Ravivanpong, P., 2012. Adoption of energy-efficiency measures in SMEs-An empirical analysis based on energy audit data from Germany. Energy Policy, 51, $863-875$

Gillingham, K., Newell, R. G., Palmer, K., 2009. Energy efficiency economics and policy (No. w15031). National Bureau of Economic Research.

Greening, L. A., Davis, W. B., Schipper, L., Khrushch, M., 1997. Comparison of six decomposition methods: application to aggregate energy intensity for manufacturing in 10 OECD countries. Energy Economics, 19, 375-390.

Greening, L., Greene, D. L., Difiglio, C., 2000. Energy efficiency and consumption-the rebound effect-a survey. Energy Policy, 28, 389-401.

Hirst, E., Brown, M., 1990. Closing the efficiency gap: barriers to the efficient use of energy. Resources, Conservation and Recycling, 3, 267-281.

Horbach, J., Rammer, C., Rennings, K., 2012. Determinants of eco-innovations by type of environmental impact-The role of regulatory push/pull, technology push and market pull. Ecological Economics, 78, 112-122.

Horbach, J., Oltra, V., Belin, J. 2013. Determinants and specificities of eco-innovations compared to other innovations - An econometric analysis for the French and German Industry based on the Community Innovation Survey, Industry and Innovation, 20, 523-543. 
IDAE, 2013. Informe anual de indicadores energéticos 2011. Instituto para la Diversificación y Ahorro de Energía, Madrid.

IEA, 2008. Worldwide Trends in Energy Use and Efficiency. Paris, France: International Energy Agency, Head of Communication and Information Office, 2008.

IEA, 2009. How the energy sector can deliver on a climate agreement in Copenhagen?. World Energy Outlook 2009. Special Report.

IEA, 2013. Key world energy statistics 2013. International Energy Agency, Paris.

Jaffe, A. B., Stavins, R. N., 1994. The energy-efficiency gap What does it mean?. Energy Policy, $22,804-810$.

Jaffe, A. B., Newell, R. G., Stavins, R. N., 2004. Economics of energy efficiency. Encyclopedia of Energy, 2, 79-90.

Khanna, M., Deltas, G., Harrington, D. R., 2009. Adoption of pollution prevention techniques: the role of management systems and regulatory pressures. Environmental and Resource Economics, 44, 85-106.

Khazzoom, J. D., 1980. Economic implications of mandated efficiency in standards for household appliances. The Energy Journal, 1, 21-40.

Leiponen, A., Helfat, C.E., 2010. Innovation Objectives, Knowledge Sources and the Benefits of Breadth, Strategic Management Journal, 31, 224-236

Linares, P., Labandeira, X., 2010. Energy efficiency: Economics and policy. Journal of Economic Surveys, 24, 573-592.

Luiten, E. E., Blok, K., 2003. Stimulating R\&D of industrial energy-efficient technology; the effect of government intervention on the development of strip casting technology. Energy Policy, 31, 1339-1356.

Luiten, E., van Lente, H., Blok, K., 2006. Slow technologies and government intervention: Energy efficiency in industrial process technologies. Technovation, 26, 1029-1044. 
Mairesse, J., Mohnen, P., 2005. The Importance of R\&D for Innovation: A Reassessment Using French Survey Data. The Journal of Technology Transfer, 30, 183-197.

Mendiluce, M., Pérez-Arriaga, I., Ocaña, C., 2010. Comparison of the evolution of energy intensity in Spain and in the EU15. Why is Spain different?. Energy Policy, 38, 639-645.

Palm, J., Thollander, P., 2010. An interdisciplinary perspective on industrial energy efficiency. Applied Energy, 87, 3255-3261.

Popp, D., Newell, R. G., Jaffe, A. B., 2009. Energy, the environment, and technological change (No. w14832). National Bureau of Economic Research.

Porter, M. E., Van der Linde, C., 1995. Green and competitive: ending the stalemate. Harvard business review, 73, 120-134.

Rennings, K., Rammer, C., 2009. Increasing energy and resource efficiency through innovationan explorative analysis using innovation survey data. ZEW-Centre for European Economic Research Discussion, (09-056).

Rohdin, P., Thollander, P., 2006. Barriers to and driving forces for energy efficiency in the nonenergy intensive manufacturing industry in Sweden. Energy, 31(12), 1836-1844.

Segarra-Oña, M. V., Peiró-Signes, A., Albors-Garrigós, J., Miret-Pastor, P., 2011. Impact of innovative practices in environmentally focused firms: moderating factors. International Journal of Environmental Research, 5, 425-434.

Sorrell, S., 2009. Jevons' Paradox revisited: The evidence for backfire from improved energy efficiency. Energy Policy, 37, 1456-1469.

Sorrell, S., Mallet, A., Nye, S., 2011. Barriers to industrial energy efficiency: A literature review. WP 10/2011. United Nations Industrial Development (UNIDO), Vienna.

Sutherland, R. J., 1991. Market barriers to energy-efficiency investments. The Energy Journal, $12,15-34$.

Sutherland, R. J., 1996. The economics of energy conservation policy. Energy Policy, 24, 361370. 
Tirole, J., 1988. The Theory of Industrial Organization. The MIT Press Cambridge, Massachusetts London.

Trianni, A., Cagno, E., 2012. Dealing with barriers to energy efficiency and SMEs: some empirical evidences. Energy, 37, 494-504.

Trianni, A., Cagno, E., Worrell, E., 2013. Innovation and adoption of energy efficient technologies: An exploratory analysis of Italian primary metal manufacturing SMEs. Energy Policy, 61, 430-440.

Uhlaner, L., Berent, M., Jeurissen, R., Wit, G., 2011. Beyond Size: Predicting engagement in environmental management practices of Dutch SMEs (No. H201118). EIM Business and Policy Research.

Urpelainen, J., 2011. Export orientation and domestic electricity generation: Effects on energy efficiency innovation in select sectors. Energy Policy, 39, 5638-5646.

Veugelers, R., 2012. Which policy instruments to induce clean innovating? Research Policy 14, $1770-1778$

Worrell, E., Bernstein, L., Roy, J., Price, L., Harnisch, J., 2009. Industrial energy efficiency and climate change mitigation. Energy Efficiency, 2, 109-123.

Worrell, E., 2011. The next frontier to realize industrial energy efficiency. In Linköping Electronic Conference Proceedings (Vol. 7, No. 057, pp. 1-13). Linköping University Electronic Press. 
Table 1. Innovative firms in the Spanish manufacturing sector

\begin{tabular}{|l|c|c|c|}
\hline & Yes & No & Total \\
\hline Firms innovating in products or processes & $\begin{array}{c}4,458 \\
(77.9 \%)\end{array}$ & $\begin{array}{c}1,263 \\
(22.1 \%)\end{array}$ & $\begin{array}{c}5,721 \\
(100.0 \%)\end{array}$ \\
\hline Firms innovating in products & 3,694 & 2,027 & 5,721 \\
& $(64.6 \%)$ & $(35.4 \%)$ & $(100.0 \%)$ \\
\hline Firms innovating in processes & 3,788 & 1,933 & 5,721 \\
& $(66.2 \%)$ & $(33.8 \%)$ & $(100.0 \%)$ \\
\hline
\end{tabular}




\begin{tabular}{|c|c|}
\hline EE & $\begin{array}{l}\text { Dichotomous variable: } 1 \text { if the firm considers the objective of } \\
\text { innovation "energy efficiency (reducing energy per unit output)" of } \\
\text { medium or high importance ( } 0 \text { if the objective has only a low } \\
\text { importance or it is not relevant) }\end{array}$ \\
\hline \multicolumn{2}{|c|}{ Independent variables } \\
\hline LSIZE & Number of employees in the firm (in log) \\
\hline LAGE & Age of the firm in years (in log) \\
\hline PRODUCTIVITY & Sales per employee (in euros) \\
\hline RDINT & $\begin{array}{l}\text { Investment in internal R\&D per employee (in thousands of euros). } \\
\text { Delayed variable }\end{array}$ \\
\hline RDEXT & $\begin{array}{l}\text { Investment in external R\&D per employee (in thousands of euros). } \\
\text { Delayed variable }\end{array}$ \\
\hline INVEST & Gross investment in tangible assets per employee (deflated) \\
\hline EXPORT & Exports as percentage of total sales \\
\hline GROUP & Categorical variable: 1 if the firm belongs to a group; 0 if not \\
\hline PRIVNAC & $\begin{array}{l}\text { Categorical variable: } 1 \text { if the firm is private with no foreign } \\
\text { shareholding; } 0 \text { if not }\end{array}$ \\
\hline FINANCE & $\begin{array}{l}\text { Dichotomous variable: } 1 \text { if the firm gets public funding from a regional, } \\
\text { national or European government for R\&D activities; } 0 \text { if not }\end{array}$ \\
\hline ECOINN & $\begin{array}{l}\text { Dichotomous variable: } 1 \text { if the firm considers the objective of } \\
\text { innovation "reduce environmental impact" of medium or high } \\
\text { importance }\end{array}$ \\
\hline REGINN & $\begin{array}{l}\text { Dichotomous variable: } 1 \text { if the firm considers the objective of } \\
\text { innovation "meet regulatory requirements" of medium or high } \\
\text { importance }\end{array}$ \\
\hline INNORG & $\begin{array}{l}\text { Dichotomous variable: } 1 \text { if the firm has introduced organizational } \\
\text { innovations (new business practices for how work is organized and } \\
\text { new company procedures); } 0 \text { if not }\end{array}$ \\
\hline SMALL & Dichotomous variable: 1 if the firm has less than 50 employees \\
\hline MEDIUM & $\begin{array}{l}\text { Dichotomous variable: } 1 \text { if the firm has between } 50 \text { and } 249 \\
\text { employees }\end{array}$ \\
\hline TIME DUMMIES & Years 2008 to 2011 \\
\hline $\begin{array}{l}\text { INDUSTRY } \\
\text { DUMMIES }\end{array}$ & $\begin{array}{l}\text { Sectors } 10 \text { to } 32 \text { (National Classification of Economic Activities, } \\
\text { CNAE2009) }\end{array}$ \\
\hline $\begin{array}{l}\text { Note: R\&D exp } \\
\text { Industrial Price } \\
\text { Source: PITEC }\end{array}$ & re and investments in tangible assets were deflated with the \\
\hline
\end{tabular}




\begin{tabular}{|c|c|c|c|}
\hline Variables & $\begin{array}{l}\text { EE objective low or } \\
\text { insignificant }\end{array}$ & $\begin{array}{c}\text { EE objective medium - } \\
\text { high }\end{array}$ & Mean difference \\
\hline SIZE & $\begin{array}{c}121.9917 \\
(348.7059) \\
\end{array}$ & $\begin{array}{c}234.0364 \\
(673.6638) \\
\end{array}$ & $\begin{array}{c}112.04 * * * \\
(9.279) \\
\end{array}$ \\
\hline AGE & $\begin{array}{c}28.7287 \\
(19.4621)\end{array}$ & $\begin{array}{c}31.1025 \\
(20.6704)\end{array}$ & $\begin{array}{c}2.3738 * * * \\
(0.3567)\end{array}$ \\
\hline PRODUCTIVITY & $\begin{array}{c}216411.2 \\
(341358.1)\end{array}$ & $\begin{array}{c}256153.6 \\
(452199.4)\end{array}$ & $\begin{array}{c}39742.2 * * * \\
(6507.62)\end{array}$ \\
\hline RDINT & $\begin{array}{c}4287.268 \\
(10685.41)\end{array}$ & $\begin{array}{l}4727.863 \\
(8954.64) \\
\end{array}$ & $\begin{array}{l}440.59 * * * \\
(177.280) \\
\end{array}$ \\
\hline RDEXT & $\begin{array}{c}941.4136 \\
(6024.747)\end{array}$ & $\begin{array}{c}870.0461 \\
(3003.758)\end{array}$ & $\begin{array}{c}71.36 \\
(87.397)\end{array}$ \\
\hline INVEST & $\begin{array}{c}9283.781 \\
(100885.8)\end{array}$ & $\begin{array}{c}11017.89 \\
(43345.06)\end{array}$ & $\begin{array}{c}1734.10 \\
(1431.34)\end{array}$ \\
\hline EXPORT & $\begin{array}{c}10.1544 \\
(17.5237) \\
\end{array}$ & $\begin{array}{c}11.2686 \\
(18.1379) \\
\end{array}$ & $\begin{array}{c}1.1142 * * * \\
(0.3173) \\
\end{array}$ \\
\hline GROUP & $\begin{array}{l}37.66 \% \\
(0.4846)\end{array}$ & $\begin{array}{l}49.87 \% \\
(0.5000)\end{array}$ & $\begin{array}{l}12.20 * * * \\
(0.0087)\end{array}$ \\
\hline FINANCE & $\begin{array}{c}32.86 \% \\
(0.4697)\end{array}$ & $\begin{array}{c}42.97 \% \\
(0.4951)\end{array}$ & $\begin{array}{l}10.11^{* * *} \\
(0.0080)\end{array}$ \\
\hline ECOINN (\% firms) & $\begin{array}{c}31.63 \% \\
(0.4651)\end{array}$ & $\begin{array}{c}81.42 \% \\
(0.3889)\end{array}$ & $\begin{array}{c}49.79 \% * * * \\
(0.0077)\end{array}$ \\
\hline REGINN (\% firms) & $\begin{array}{c}37.86 \% \\
(0.4851)\end{array}$ & $\begin{array}{l}80.92 \% \\
(0.3930)\end{array}$ & $\begin{array}{c}43.05 \% * * * \\
(0.0079)\end{array}$ \\
\hline $\begin{array}{l}\text { INNORG (\% firms with } \\
\text { organizational innovations) }\end{array}$ & $\begin{array}{c}42.19 \% \\
(0.4939)\end{array}$ & $\begin{array}{c}64.33 \% \\
(0.4791)\end{array}$ & $\begin{array}{c}22.14 \% * * * \\
(0.0086)\end{array}$ \\
\hline \multicolumn{4}{|c|}{$\begin{array}{l}\text { Note: Comparison of the two samples by the statistical t-test; } * * * \text { significant at } 1 \% \text {. } \\
43.6 \% \text { of all innovative firms consider that energy efficiency is an innovation objective of medium-high } \\
\text { importance. }\end{array}$} \\
\hline
\end{tabular}


Table 4. Energy intensity. Manufacturing industries (average 2008-2011)

\begin{tabular}{|l|c|}
\hline TOTAL INDUSTRY & $2,98 \%$ \\
\hline Extractive petroleum industry (CNAE 05, 06, 07, 08, 09, 19) & $2,04 \%$ \\
\hline Food (CNAE 10) & $2,63 \%$ \\
\hline Beverage and tobacco (CNAE 11, 12) & $1,73 \%$ \\
\hline Textile, clothing, leather and footwear industries (CNAE 13, 14, 15) & $2,43 \%$ \\
\hline Wood and cork (CNAE 16) & $4,35 \%$ \\
\hline Pulp, Paper and printing (CNAE 17, 18) & $5,64 \%$ \\
\hline Chemical industry (CNAE 20) & $5,18 \%$ \\
\hline Pharmaceutical industry (CNAE 21) & $1,35 \%$ \\
\hline Rubber and plastic products (CNAE 22) & $3,50 \%$ \\
\hline Other non-metallic mineral products (CNAE 23) & $8,99 \%$ \\
\hline Metallurgy (CNAE 24) & $6,23 \%$ \\
\hline Manufacture of fabricated metal products, except machinery and equipment (CNAE & \\
\hline 25$)$ & $2,11 \%$ \\
\hline Electrical, electronic and optical material and equipment (CNAE 26, 27) & $1,04 \%$ \\
\hline Machinery and mechanical equipment (CNAE 28) & $1,10 \%$ \\
\hline Motor vehicles, trailers and semi-trailers (CNAE 29) & $0,90 \%$ \\
\hline Transport equipment, except motor vehicles (CNAE 30) & $0,74 \%$ \\
\hline Furniture and other manufacturing industries (CNAE 31, 32) & $2,05 \%$ \\
\hline Source: Encuesta Industial de Empresas" (Survey of Industril Enterprises), INE, Spain
\end{tabular}

Source: "Encuesta Industrial de Empresas" (Survey of Industrial Enterprises), INE, Spain.

Note: Energy Intensity is calculated as Acquisitions of Energy Products divided by Net Sales of Products (as a percentage). 
Table 5. Correlation matrix

\begin{tabular}{|c|c|c|c|c|c|c|c|c|c|c|c|c|c|c|}
\hline I & $\mathrm{EE}$ & LSIZE & LAGE & PRODUCT. & RDINT & RDEXT & INVEST & EXPORT & GROUP & PRIVNAC & FINANCE & ECOINN & REGINN & INNORGN \\
\hline $\mathrm{EE}$ & 1 & & & & & & & & & & & & & \\
\hline LSIZE & 0.1710 & 1 & & & & & & & & & & & & \\
\hline LAGE & 0.0504 & 0.2978 & 1 & & & & & & & & & & & \\
\hline PRODUCTIVITY & 0.0500 & 0.1355 & 0.0601 & 1 & & & & & & & & & & \\
\hline RDINT & -0.0052 & -0.3966 & -0.1619 & -0.0473 & 1 & & & & & & & & & \\
\hline RDEXT & -0.0087 & -0.2352 & -0.1149 & -0.0052 & 0.3788 & 1 & & & & & & & & \\
\hline INVEST & 0.0386 & 0.1502 & 0.0393 & 0.1384 & -0.0243 & -0.0143 & 1 & & & & & & & \\
\hline EXPORT & 0.0377 & 0.0569 & 0.0696 & 0.0299 & -0.0109 & 0.0116 & 0.0231 & 1 & & & & & & \\
\hline GROUP & 0.1143 & 0.5181 & 0.0811 & 0.1826 & -0.1715 & -0.0805 & 0.0603 & 0.0484 & 1 & & & & & \\
\hline PRIVNAC & -0.0763 & -0.3650 & -0.0666 & -0.1135 & 0.1190 & 0.0656 & -0.0733 & -0.0194 & -0.4270 & 1 & & & & \\
\hline FINANCE & 0.1037 & 0.1740 & 0.0349 & 0.0308 & 0.0508 & 0.1152 & 0.0439 & 0.0996 & 0.1042 & 0.0269 & 1 & & & \\
\hline ECOINN & 0.5018 & 0.1823 & 0.0678 & 0.0491 & 0.0251 & 0.0071 & 0.0304 & 0.0293 & 0.1075 & -0.0606 & 0.1656 & 1 & & \\
\hline REGINN & 0.4435 & 0.1392 & 0.0448 & 0.0210 & 0.0442 & 0.0088 & 0.0154 & 0.0500 & 0.0702 & -0.0401 & 0.1441 & 0.6799 & 1 & \\
\hline INNORG & 0.2075 & 0.2073 & 0.0442 & 0.0355 & -0.0316 & -0.0060 & 0.0428 & 0.0456 & 0.1165 & -0.0647 & 0.1406 & 0.2249 & 0.2439 & 1 \\
\hline
\end{tabular}




\begin{tabular}{|c|c|c|c|c|c|c|c|}
\hline VARIABLES & $\begin{array}{c}(1) \\
\text { TOTAL } \\
(10 \ldots 32)\end{array}$ & $\begin{array}{l}\text { (2) } \\
\text { PAPER } \\
(17)\end{array}$ & $\begin{array}{c}\text { (3) } \\
\text { CHEMICALS } \\
(20)\end{array}$ & $\begin{array}{c}\text { (4) } \\
\text { NONMETALLIC } \\
\text { MINERAL } \\
(23) \\
\end{array}$ & $\begin{array}{c}\text { (5) } \\
\text { METALS AND METAL } \\
\text { PRODUCTS (24-25) }\end{array}$ & $\begin{array}{c}\text { (6) } \\
\text { OTHER SECTORS }\end{array}$ & $\begin{array}{c}(7) \\
\text { TOTAL } \\
(10 \ldots 32)\end{array}$ \\
\hline LSIZE & $\begin{array}{r}0.0979 * * * \\
(0.0299)\end{array}$ & $\begin{array}{r}0.160 \\
(0.272)\end{array}$ & $\begin{array}{r}0.107 \\
(0.100)\end{array}$ & $\begin{array}{r}-0.179 \\
(0.130)\end{array}$ & $\begin{array}{r}0.0167 \\
(0.0982)\end{array}$ & $\begin{array}{r}0.114 * * * \\
(0.0354)\end{array}$ & \\
\hline LAGE & $\begin{array}{r}-0.0222 \\
(0.0419)\end{array}$ & $\begin{array}{r}-0.0967 \\
(0.281)\end{array}$ & $\begin{array}{l}-0.194^{*} \\
(0.110)\end{array}$ & $\begin{array}{l}0.332^{*} \\
(0.194)\end{array}$ & $\begin{array}{l}-0.0447 \\
(0.133)\end{array}$ & $\begin{array}{r}-0.00222 \\
(0.0513)\end{array}$ & $\begin{array}{r}-0.00845 \\
(0.0415)\end{array}$ \\
\hline PRODUCIVITY & $\begin{array}{l}1.37 \mathrm{e}-07^{*} \\
(7.32 \mathrm{e}-08)\end{array}$ & $\begin{array}{r}-4.72 \mathrm{e}-07 \\
(1.18 \mathrm{e}-06)\end{array}$ & $\begin{array}{r}1.13 \mathrm{e}-07 \\
(3.24 \mathrm{e}-07)\end{array}$ & $\begin{array}{r}2.03 \mathrm{e}-08 \\
(2.63 \mathrm{e}-07)\end{array}$ & $\begin{array}{r}3.71 \mathrm{e}-07^{* *} \\
(1.76 \mathrm{e}-07)\end{array}$ & $\begin{array}{r}1.02 \mathrm{e}-07 \\
(7.47 \mathrm{e}-08)\end{array}$ & $\begin{array}{l}1.40 \mathrm{e}-07^{*} \\
(7.33 \mathrm{e}-08)\end{array}$ \\
\hline RDINT_1 & $\begin{array}{r}0.642 \\
(0.628)\end{array}$ & $\begin{array}{r}15.73 \\
(17.27)\end{array}$ & $\begin{array}{r}-2.313 \\
(3.194)\end{array}$ & $\begin{array}{l}-6.699 * \\
(3.784)\end{array}$ & $\begin{array}{r}2.984 \\
(3.206)\end{array}$ & $\begin{array}{r}1.061 \\
(0.658)\end{array}$ & $\begin{array}{r}0.150 \\
(0.618)\end{array}$ \\
\hline RDEXT_1 & $\begin{array}{l}0.0225 \\
(0.879)\end{array}$ & $\begin{array}{r}-32.24 \\
(22.69)\end{array}$ & $\begin{array}{r}-0.844 \\
(3.191)\end{array}$ & $\begin{array}{l}-5.881 \\
(6.669)\end{array}$ & $\begin{array}{r}-4.931 \\
(3.784)\end{array}$ & $\begin{array}{r}0.576 \\
(0.919)\end{array}$ & $\begin{array}{r}-0.212 \\
(0.889)\end{array}$ \\
\hline INVEST & $\begin{array}{r}1.65 \mathrm{e}-09 * * \\
(7.59 \mathrm{e}-10)\end{array}$ & $\begin{array}{l}6.83 e-08 * \\
(3.95 e-08)\end{array}$ & $\begin{array}{r}3.82 \mathrm{e}-09 \\
(2.95 \mathrm{e}-09)\end{array}$ & $\begin{array}{r}3.59 \mathrm{e}-08^{* *} \\
(1.66 \mathrm{e}-08)\end{array}$ & $\begin{array}{r}-1.25 e-08 \\
(4.28 e-08)\end{array}$ & $\begin{array}{l}1.46 \mathrm{e}-09 * \\
(7.83 \mathrm{e}-10)\end{array}$ & $\begin{array}{r}1.76 \mathrm{e}-09 * * \\
(7.66 \mathrm{e}-10)\end{array}$ \\
\hline EXPORT & $\begin{array}{l}0.00281^{*} \\
(0.00157)\end{array}$ & $\begin{array}{l}-0.00199 \\
(0.0213)\end{array}$ & $\begin{array}{r}0.00383 \\
(0.00362)\end{array}$ & $\begin{array}{r}0.0120 \\
(0.0126)\end{array}$ & $\begin{array}{r}0.00524 \\
(0.00513)\end{array}$ & $\begin{array}{r}0.00214 \\
(0.00187)\end{array}$ & $\begin{array}{l}0.00300^{*} \\
(0.00157)\end{array}$ \\
\hline GROUP & $\begin{array}{r}0.105 \\
(0.0718)\end{array}$ & $\begin{array}{r}-0.126 \\
(0.455)\end{array}$ & $\begin{array}{r}0.254 \\
(0.201)\end{array}$ & $\begin{array}{r}0.427 \\
(0.305)\end{array}$ & $\begin{array}{r}0.227 \\
(0.217)\end{array}$ & $\begin{array}{r}0.0205 \\
(0.0866)\end{array}$ & $\begin{array}{r}0.129 * \\
(0.0709)\end{array}$ \\
\hline PRIVNAC & $\begin{array}{r}-0.0993 \\
(0.0835)\end{array}$ & $\begin{array}{r}-0.272 \\
(0.565)\end{array}$ & $\begin{array}{l}0.0563 \\
(0.209)\end{array}$ & $\begin{array}{r}0.209 \\
(0.326)\end{array}$ & $\begin{array}{r}0.316 \\
(0.324)\end{array}$ & $\begin{array}{l}-0.195^{*} \\
(0.101)\end{array}$ & $\begin{array}{r}-0.107 \\
(0.0838)\end{array}$ \\
\hline FINANCE & $\begin{array}{r}-0.0124 \\
(0.0550)\end{array}$ & $\begin{array}{r}0.607 \\
(0.424)\end{array}$ & $\begin{array}{r}-0.0314 \\
(0.145)\end{array}$ & $\begin{array}{r}0.201 \\
(0.241)\end{array}$ & $\begin{array}{r}0.121 \\
(0.182)\end{array}$ & $\begin{array}{r}-0.0444 \\
(0.0672)\end{array}$ & $\begin{array}{l}0.00166 \\
(0.0548)\end{array}$ \\
\hline ECOINN & $\begin{array}{r}1.590 * * * \\
(0.0707)\end{array}$ & $\begin{array}{r}2.395 * * * \\
(0.565)\end{array}$ & $\begin{array}{r}1.187^{* * *} \\
(0.213)\end{array}$ & $\begin{array}{r}1.364^{* * *} \\
(0.335)\end{array}$ & $\begin{array}{r}1.913 * * * \\
(0.214)\end{array}$ & $\begin{array}{r}1.604 * * * \\
(0.0831)\end{array}$ & $\begin{array}{r}1.595 * * * \\
(0.0706)\end{array}$ \\
\hline REGINN & $\begin{array}{r}0.931 * * * \\
(0.0701)\end{array}$ & $\begin{array}{r}0.343 \\
(0.502)\end{array}$ & $\begin{array}{r}1.044 * * * \\
(0.206)\end{array}$ & $\begin{array}{r}1.271^{* * *} \\
(0.307)\end{array}$ & $\begin{array}{r}0.855^{* * *} \\
(0.216)\end{array}$ & $\begin{array}{r}0.924 * * * \\
(0.0837)\end{array}$ & $\begin{array}{r}0.937 * * * \\
(0.0699)\end{array}$ \\
\hline INNORG & $\begin{array}{r}0.391 * * * \\
(0.0555)\end{array}$ & $\begin{array}{r}0.477 \\
(0.383)\end{array}$ & $\begin{array}{r}0.319 * * \\
(0.150)\end{array}$ & $\begin{array}{r}0.508^{* *} \\
(0.241)\end{array}$ & $\begin{array}{r}0.377^{* *} \\
(0.166)\end{array}$ & $\begin{array}{r}0.404 * * * \\
(0.0677)\end{array}$ & $\begin{array}{r}0.401^{* * *} \\
(0.0554)\end{array}$ \\
\hline SMALL & & & & & & & $\begin{array}{r}-0.287^{* * *} \\
(0.104)\end{array}$ \\
\hline MEDIUM & & & & & & & $\begin{array}{r}-0.201 * * \\
(0.0914)\end{array}$ \\
\hline Constant & $\begin{array}{r}-2.634^{* * *} \\
(0.350)\end{array}$ & $\begin{array}{r}-1.786 \\
(1.283)\end{array}$ & $\begin{array}{r}-1.580 * * * \\
(0.535)\end{array}$ & $\begin{array}{r}-2.628^{* * *} \\
(0.778)\end{array}$ & $\begin{array}{r}-2.420^{* * *} \\
(0.635)\end{array}$ & $\begin{array}{r}-2.677^{* * *} \\
(0.374)\end{array}$ & $\begin{array}{r}-2.082^{* * *} \\
(0.357)\end{array}$ \\
\hline Observations & 14,872 & 306 & 1,946 & 790 & 1,621 & 10,209 & 14,872 \\
\hline Wald Chi-squared & 1810.37 & 77.53 & 179.05 & 115.72 & 245.59 & 1251.22 & 1813.55 \\
\hline Pseudo R_squared & 0.228 & 0.335 & 0.158 & 0.262 & 0.259 & 0.234 & 0.228 \\
\hline
\end{tabular}

Robust standard errors in parentheses, ${ }^{* * *} p<0.01,{ }^{* *} p<0.05,{ }^{*} p<0.1$

All the estimations include year dummies and the estimations (1) and (7) include also a set of 20 industry dummies. 


\begin{tabular}{|c|c|c|c|c|c|c|c|}
\hline VARIABLES & $\begin{array}{c}\text { (1) } \\
\text { TOTAL } \\
\text { (10...32) }\end{array}$ & $\begin{array}{c}\text { (2) } \\
\text { PAPER } \\
(17)\end{array}$ & $\begin{array}{c}\text { (3) } \\
\text { CHEMICALS } \\
(20)\end{array}$ & $\begin{array}{c}(4) \\
\text { NONMETALLIC } \\
\text { MINERAL } \\
(23) \\
\end{array}$ & $\begin{array}{c}\text { (5) } \\
\text { METALS AND } \\
\text { METAL } \\
\text { PRODUCTS (24-25) } \\
\end{array}$ & $\begin{array}{c}\text { (6) } \\
\text { OTHER } \\
\text { SECTORS }\end{array}$ & $\begin{array}{c}(7) \\
\text { TOTAL } \\
(10 \ldots 32)\end{array}$ \\
\hline LSIZE & $\begin{array}{r}0.0236 * * * \\
(0.00722)\end{array}$ & $\begin{array}{r}0.0374 \\
(0.0637)\end{array}$ & $\begin{array}{r}0.0268 \\
(0.0250)\end{array}$ & $\begin{array}{r}-0.0444 \\
(0.0321)\end{array}$ & $\begin{array}{l}0.00388 \\
(0.0228)\end{array}$ & $\begin{array}{r}0.0273 * * * \\
(0.00843)\end{array}$ & \\
\hline LAGE & $\begin{array}{r}-0.00536 \\
(0.0101)\end{array}$ & $\begin{array}{r}-0.0226 \\
(0.0659)\end{array}$ & $\begin{array}{c}-0.0484^{*} \\
(0.0274)\end{array}$ & $\begin{array}{l}0.0822^{*} \\
(0.0481)\end{array}$ & $\begin{array}{r}-0.0104 \\
(0.0309)\end{array}$ & $\begin{array}{r}-0.000529 \\
(0.0122)\end{array}$ & $\begin{array}{r}-0.00204 \\
(0.0100)\end{array}$ \\
\hline PRODUCTIVITY & $3.30 \mathrm{e}-08 *$ & $\begin{array}{r}-1.10 \mathrm{e}-07 \\
(2.76 \mathrm{e}-\end{array}$ & $2.82 \mathrm{e}-08$ & $5.03 e-09$ & $8.61 \mathrm{e}-08^{* *}$ & $2.43 e-08$ & $3.38 \mathrm{e}-08^{*}$ \\
\hline & (1.77e-08) & 07) & (8.07e-08) & (6.50e-08) & $(4.07 e-08)$ & $(1.78 \mathrm{e}-08)$ & $(1.77 e-08)$ \\
\hline RDINT_1 & $\begin{array}{r}0.155 \\
(0.152)\end{array}$ & $\begin{array}{r}3.685 \\
(-4.069)\end{array}$ & $\begin{array}{r}-0.577 \\
(0.796)\end{array}$ & $\begin{array}{r}-1.658^{*} \\
(0.939)\end{array}$ & $\begin{array}{r}0.693 \\
(0.745)\end{array}$ & $\begin{array}{r}0.253 \\
(0.157)\end{array}$ & $\begin{array}{l}0.0361 \\
(0.149)\end{array}$ \\
\hline RDEXT_1 & $\begin{array}{r}0.00543 \\
(0.212)\end{array}$ & $\begin{array}{r}-7.551 \\
(-5.194)\end{array}$ & $\begin{array}{r}-0.210 \\
(0.796)\end{array}$ & $\begin{array}{r}-1.455 \\
(-1.652)\end{array}$ & $\begin{array}{r}-1.145 \\
(0.881)\end{array}$ & $\begin{array}{r}0.137 \\
(0.219)\end{array}$ & $\begin{array}{r}-0.0511 \\
(0.215)\end{array}$ \\
\hline INVEST & $3.99 \mathrm{e}-10^{* *}$ & $\begin{array}{r}1.60 \mathrm{e}-08^{*} \\
(9.30 \mathrm{e}-\end{array}$ & $9.52 \mathrm{e}-10$ & $8.89 e-09 * *$ & $-2.90 e-09$ & $3.47 e-10 *$ & $\begin{array}{r}4.25 \mathrm{e}- \\
10^{* *}\end{array}$ \\
\hline EXPORT & $\begin{array}{l}(1.83 e-10) \\
0.000679^{*} \\
(0.000378)\end{array}$ & $\begin{array}{r}09) \\
-0.000465 \\
(0.00498)\end{array}$ & $\begin{array}{r}(7.36 e-10) \\
0.000954 \\
(0.000902)\end{array}$ & $\begin{array}{r}(4.12 \mathrm{e}-09) \\
0.00297 \\
(0.00312)\end{array}$ & $\begin{array}{r}(9.93 e-09) \\
0.00122 \\
(0.00119)\end{array}$ & $\begin{array}{r}(1.87 e-10) \\
0.000510 \\
(0.000445)\end{array}$ & $\begin{array}{l}(1.85 e-10) \\
0.000725^{*} \\
(0.000380)\end{array}$ \\
\hline GROUP & $\begin{array}{r}0.0254 \\
(0.0174)\end{array}$ & $\begin{array}{r}-0.0294 \\
(0.106)\end{array}$ & $\begin{array}{r}0.0632 \\
(0.0499)\end{array}$ & $\begin{array}{r}0.105 \\
(0.0748)\end{array}$ & $\begin{array}{r}0.0533 \\
(0.0512)\end{array}$ & $\begin{array}{l}0.00489 \\
(0.0207)\end{array}$ & $\begin{array}{l}0.0313^{*} \\
(0.0172)\end{array}$ \\
\hline PRIVNAC & $\begin{array}{r}-0.0241 \\
(0.0204)\end{array}$ & $\begin{array}{r}-0.0623 \\
(0.127)\end{array}$ & $\begin{array}{r}0.0140 \\
(0.0519)\end{array}$ & $\begin{array}{r}0.0512 \\
(0.0793)\end{array}$ & $\begin{array}{r}0.0706 \\
(0.0692)\end{array}$ & $\begin{array}{r}-0.0470 * \\
(0.0247)\end{array}$ & $\begin{array}{r}-0.0259 \\
(0.0204)\end{array}$ \\
\hline FINANCE & $\begin{array}{r}-0.00299 \\
(0.0133)\end{array}$ & $\begin{array}{r}0.136 \\
(0.0897)\end{array}$ & $\begin{array}{r}-0.00782 \\
(0.0361)\end{array}$ & $\begin{array}{r}0.0497 \\
(0.0600)\end{array}$ & $\begin{array}{r}0.0282 \\
(0.0426)\end{array}$ & $\begin{array}{r}-0.0106 \\
(0.0160)\end{array}$ & $\begin{array}{r}0.000400 \\
(0.0132)\end{array}$ \\
\hline ECOINN & $\begin{array}{r}0.365^{* * *} \\
(0.0147)\end{array}$ & $\begin{array}{r}0.527^{* * *} \\
(0.101)\end{array}$ & $\begin{array}{r}0.281^{* * *} \\
(0.0459)\end{array}$ & $\begin{array}{r}0.323 * * * \\
(0.0729)\end{array}$ & $\begin{array}{r}0.426 * * * \\
(0.0428)\end{array}$ & $\begin{array}{r}0.367 * * * \\
(0.0174)\end{array}$ & $\begin{array}{r}0.366^{* * *} \\
(0.0147)\end{array}$ \\
\hline REGINN & $\begin{array}{r}0.220 * * * \\
(0.0159)\end{array}$ & $\begin{array}{l}0.0804 \\
(0.118)\end{array}$ & $\begin{array}{r}0.250 * * * \\
(0.0458)\end{array}$ & $\begin{array}{r}0.304 * * * \\
(0.0686)\end{array}$ & $\begin{array}{r}0.197 * * * \\
(0.0481)\end{array}$ & $\begin{array}{r}0.216 * * * \\
(0.0188)\end{array}$ & $\begin{array}{r}0.221^{* * *} \\
(0.0158)\end{array}$ \\
\hline INNORG & $\begin{array}{r}0.0947^{* * *} \\
(0.0134)\end{array}$ & $\begin{array}{r}0.110 \\
(0.0874)\end{array}$ & $\begin{array}{r}0.0793 * * \\
(0.0373)\end{array}$ & $\begin{array}{l}0.126^{* *} \\
(0.0594)\end{array}$ & $\begin{array}{r}0.0880 * * \\
(0.0391)\end{array}$ & $\begin{array}{r}0.0967 * * * \\
(0.0162)\end{array}$ & $\begin{array}{r}0.0970 * * * \\
(0.0134)\end{array}$ \\
\hline SMALL & & & & & & & $\begin{array}{r}- \\
0.0691 * * * \\
(0.0249)\end{array}$ \\
\hline MEDIUM & & & & & & & $\begin{array}{r}-0.0482 * * \\
(0.0218) \\
\end{array}$ \\
\hline & & & & & & & \\
\hline Probab & 0.407 & 0.626 & 0.474 & 0.450 & 0.367 & 0.392 & 0.407 \\
\hline EE. Mean & 0.436 & 0.581 & 0.491 & 0.468 & 0.406 & 0.423 & 0.436 \\
\hline
\end{tabular}

$* * *, * *$ and $*$ denote statistical significance at the 1,5 and $10 \%$ levels respectively.

Marginal effects calculated at their means. For dummy variables, change in probability for a discrete change of the dummy variable from 0 to 1. 